\title{
Addendum \\ Addendum: López-Vidal et al. Is Autophagy Involved in Pepper Fruit Ripening? Cells 2020, 9, 106
}

\author{
Omar López-Vidal $^{1}$, Adela Olmedilla ${ }^{2}$ (D) Luisa María Sandalio ${ }^{2}$, Francisca Sevilla ${ }^{1}$ (D) and Ana Jiménez ${ }^{1, *(\mathbb{D})}$ \\ 1 Department of Stress Biology and Plant Pathology, CEBAS-CSIC, 30100 Murcia, Spain; \\ omalopez17@yahoo.com (O.L.-V.); fsevilla@cebas.csic.es (F.S.) \\ 2 Department of Biochemistry, Cellular and Molecular Biology of Plants, EEZ-CSIC, 18160 Granada, Spain; \\ adela.olmedilla@eez.csic.es (A.O.); luisamaria.sandalio@eez.csic.es (L.M.S.) \\ * Correspondence: ajimenez@cebas.csic.es; Tel.: +34-968-396200
}

Citation: López-Vidal, O.; Olmedilla, A.; Sandalio, L.M.; Sevilla, F.; Jiménez, A. Addendum: López-Vidal et al. Is Autophagy Involved in Pepper Fruit Ripening? Cells 2020, 9, 106. Cells 2021, 10, 1766. https://doi.org/ 10.3390/cells10071766

Received: 14 May 2021

Accepted: 25 May 2021

Published: 13 July 2021

Publisher's Note: MDPI stays neutral with regard to jurisdictional claims in published maps and institutional affiliations.

The authors would like to make an addendum to their published paper [1].

In the version of this article originally published, a key funding source was omitted, so the authors wish to add the funding project "RED2018-102397-T".

The change does not affect the scientific results.

The rest of the manuscript does not need to be changed.

The authors would like to apologize for any inconvenience caused.

\section{Reference}

1. López-Vidal, O.; Olmedilla, A.; Sandalio, L.M.; Sevilla, F.; Jiménez, A. Is Autophagy Involved in Pepper Fruit Ripening? Cells 2020, 9, 106. [CrossRef] [PubMed] 